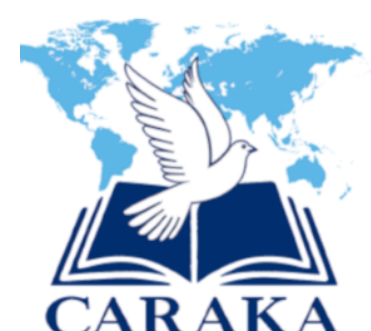

\begin{tabular}{|l|l|l|}
\hline Diserahkan: 21 Juli 2020 & Diterima: 09 September 2020 & Diterbitkan: 28 September 2020 \\
\hline
\end{tabular}

\title{
PERSPEKTIF GEREJA MASEHI INJIL DI TIMOR (GMIT) IMANUEL MATEPU TERHADAP TRADISI PURU HOGO
}

\author{
Indah L. Basuki, Chlaoudhius Budhianto, Iskak Sugiyarto \\ Sekolah Tinggi Teologi Sangkakala \\ indahbasuki01@gmail.com \\ chlaoudhius@yahoo.co.id \\ iskaksugiyarto78@gmail.com
}

\begin{abstract}
Puru Hogo is a tradition that is still attached to the life of the Sabu tribe in East Nusa Tenggara. The Puru Hogo tradition is carried out by the Sabu community every year, when they want to do the extracting of sap and cooking sugar, in June and July. They believe that they will be blessed, the results of the extraction of sap will be good, no one will have an accident, and they will get a good income, on condition that they have to offer a sheep to give to Mone Ama. Using a qualitative approach, a descriptive method, this research examines the perspective of the Christian Church in Timor (GMIT) Imanuel Matepu. It was found that the Puru Hogo tradition was given a new meaning, so that it became a bridge for church ministry in the Sabu community.
\end{abstract}

Keywords: Puru Hogo Tradition; Contextual; Sabu Tribe.

\begin{abstract}
Abstrak
Puru Hogo merupakan tradisi yang masih lekat dalam kehidupan Suku Sabu di Nusa Tenggara Timur. Tradisi Puru Hogo dilakukan oleh masyarakat Sabu setiap tahun, saat hendak melakukan pengambilan air nira dan memasak gula, pada bulan Juni dan Juli. Mereka meyakini bahwa mereka akan diberkati, hasil pengambilan air nira akan bagus, tidak ada yang mengalami kecelakaan, dan mereka akan mendapatkan pendapatan yang baik, dengan syarat harus mempersembahkan seekor domba untuk diberikan kepada Mone Ama. Melalui metode kualitatif dengan menggunakan pendekatan deskriptif, penelitian ini menelisik tentang perspektif Gereja Masehi Injil di Timor (GMIT) Imanuel Matepu. Di dapati bahwa tradisi Puru Hogo, diberi makna baru, sehingga menjadi jembatan bagi pelayanan gereja di masyarakat Sabu.
\end{abstract}

Kata Kunci: Tradisi Puru Hogo; Kontekstual; Suku Sabu 


\section{PENDAHULUAN}

Indonesia terkenal dengan banyak sekali keanekaragaman budaya yang unik. Gereja perlu peka dan kritis, di samping tetap melihat keindahan dari budaya yang beragam tersebut. Oleh sebab itu, Gereja seyogyanya menjalin relasi antara eksistensinya dengan budaya yang ada. Robert J. Schreiter menegaskan untuk mempunyai sikap peka dan terbuka pada situasi kondisi lokal yang ada. Keterbukaan akan lokalitas masyarakat yang ada akan berimplikasi pada strategi pengembangan penginjilan, serta pelayanan yang berusaha menemukan Kristus dalam konteks lokalnya, dan bukan usaha untuk memasukkan Kristus ke dalamnya. ${ }^{1}$

Acapkali terjadi dualisme, bahwa yang melakukan ritual sesuai dengan masyarakat lokal dinilai tidak mencerminkan kekristenan yang sejati. Namun, Paulus menegaskan dan memberi teladan mengenai bagaimana menjadi manusia seutuhnya, mengikuti aturan Tuhan dan aturan budaya setempat (I Korintus 9:20). Oleh sebab itu, diperlukan sebuah dialog untuk dapat menjembatani hal tersebut. Berdialog berbeda dengan mengafirmasi atau mengkonfirmasi, tetapi lebih ke arah diskusi (berbincang-bincang) untuk membuka titik temu antara nilai yang diyakini oleh gereja dan masyarakat. Dari sisi gereja, supaya tidak mudah menyesatkan, dan sebaliknya dari sisi masyarakat mempunyai pemahaman bahwa Kristen tidak identik dengan agama asing. Pertemuan dialogis inilah yang menjadi stimulasi untuk mengikis asumsi-asumsi yang salah di dalam masyarakat, sehingga kekristenan dapat tetap menjadi saksi di tengah masyarakat. ${ }^{2}$

Dialog menjadi stimulan untuk mengembangkan harmoni dalam masyarakat, dan menumbuhkan kembali nilai-nilai untuk membangun komunitas yang dipenuhi dengan keadilan, cinta kasih dan perdamaian. Diperlukan pemahaman yang lebih mendalam terkait evangelisasi, bukan hanya sekadar mengkristenkan orang dan menaifkan budaya, tetapi lebih kepada menghayati nilai-nilai iman dalam kehidupan keseharian. Oleh sebab itu, penghormatan akan budaya dan pemahaman tentang Injil menjadi penting, sehingga kedua hal tersebut dapat saling bersatu. ${ }^{3}$ Selain itu untuk mampu berada di tengah kultur budaya yang ada, maka diperlukan karakter dan perilaku yang baik juga, sehingga dimanapun dan kapan pun bisa menjadi terang yang mewarnai seluruh kehidupan dalam masyarakat (Matius 5:16). ${ }^{4}$

Menurut Tari, ada tiga alasan mengapa teologi memerlukan usaha inkulturasi atau kontekstualisasi. Pertama, penghayatan iman Kristen yang mendasarkan pada Injil Yesus

\footnotetext{
${ }^{1}$ Winfrid Prayogi, "Mencari Esensi Dan Misi Gereja Dalam Konteks Indonesia Awal Abad 21," Veritas : Jurnal Teologi dan Pelayanan 1, no. 1 (2000): 10.

2 Ayub Warjianto and Fibry Jati Nugroho, “Teologi Penghormatan,” Visio Dei: Jurnal Teologi Kristen 2, no. 1 (2020): 147.

3 Y Hariprabowo, "Misi Gereja Di Tengah Pluralitas Agama Dan Budaya,” Orientasi Baru 18, no. 1 (2009): 13-14.

4 Desty Samarenna, “Berteologi Dalam Konteks Indonesia Modern,” Evangelikal: Jurnal Teologi Injili dan Pembinaan Warga Gereja 1, no. 1 (2017): 25.
} 
Kristus selalu terjadi pada situasi, lingkungan, konteks atau budaya tertentu yang konkret. Kedua, konteks konkret atau tata budaya konkret bukanlah objek melainkan subjek yang aktif. Nilai manusiawi yang terkandung di situ dibutuhkan untuk memperkaya penghayatan Iman kepada Yesus Kristus. Ketiga, menjadi beriman berarti dipanggil untuk menjadi ciptaan baru (2 Kor5:15, 17-18). ${ }^{5}$

Kekristenan meyakini bahwa Alkitab merupakan pewahyuan dari Allah yang menyatakan natur, sifat dan karya Allah, didalamnya dapat diperoleh pengetahuan esensi tentang Allah. Alkitab memberi pernyataan bahwa manusia dapat melihat Allah oleh dasar anugerah semata (Ul. 7:7-8; Tit. 6:5). Pengenalan akan Allah, seharusnya bukan hanya dilakukan secara intelektual dan abstrak saja, tetapi berwujud dalam eksperensial dan personal. Kekristenan memandang bahwa apa yang diijinkan terjadi pada kehidupan manusia merupakan sebuah anugrah dan bukan hasil jerih lelah manusia. Iman Kristen menyatakan bahwa sejak kejatuhan manusia dalam dosa, citra Allah dalam dirinya sudah rusak. Oleh karena anugrah dan kemurahan Allah saja, gambaran Allah dalam diri manusia dapat dipulihkan dalam keadaan semula. Maka dari itu, kekristenan didasari bahwa segala sesuatu berasal dari Allah, oleh Allah dan bagi kemuliaan Allah. ${ }^{6}$ Dari penelitian-penelitian terkait injil dan budaya, belum terdapat hasil penelitian terkait tradisi Puru Hogo yang ada di wilayah Sabu Seba. Tulisan ini akan melengkapi penelitian-penelitian yang ada, dengan mendeskripsikan perspektif Gereja Masehi Injil Di Timor (GMIT) Imanuel Matepu terhadap tradisi Puru Hogo di Sabu Seba.

\section{METODE PENELITIAN}

Metode yang digunakan dalam penelitian ini yaitu memakai metode deskriptif analisis dengan pendekatan kualitatif. Pendekatan kualitatif digunakan untuk menggambarkan fenomena-fenomena yang ada, baik yang bersifat alamiah ataupun rekayasa serta menemukan makna baru dalam suatu peristiwa. ${ }^{7}$ Teknik observasi dan wawancara juga dilakukan, sehingga data yang diterima jelas.

\section{HASIL DAN PEMBAHASAN}

Dari kalangan orang Kristen sendiri, terkadang kalau berbicara tentang tradisi akan menimbulkan pro dan kontra, karena ada beberapa kelompok orang Kristen yang menyetujui kebudayaan, bahkan itu dipakai sebagai teologi konteksual tetapi ada beberapa kelompok

5 Ezra Tari, “Teologi Tongkonan: Berteologi Dalam Konteks Budaya Toraja,” EPIGRAPHE: Jurnal Teologi dan Pelayanan Kristiani 2, no. 2 (2018): 5.

6 James A. Lola, "Iman Kristen Dan Budaya Popular," Visio Dei: Jurnal Teologi Kristen 1, no. 1 (2019): 13-14.

7 Nana Syaodih Sukmadimata, Metode Penelitian Pendidikan (Bandung: Remaja Rosdakarya, 2011), 72. 106 | Copyright $\odot$ 2020, CARAKA, ISSN 2722-1407 (Cetak), 2722-1393 (Online) 
Kristen yang tidak menyetujui karena melihat tradisi tersebut tidak sesuai dengan kebenaran Alkitab. H. Richard Niebuhr memaparkan bahwa hubungan antara Kekristenan dan kebudayaan ditandai dengan tiga tipe. Pertama, Kristus menentang kebudayaan. Kedua, Kristus dari kebudayaan dan yang ketiga, jalan tengah antara Kristus menentang kebudayaan dan Kristus dari kebudayaan. ${ }^{8}$ Jadi dalam hal ini gereja memiliki peranan yang sangat penting dalam memberikan nilai-nilai kebenaran dalam membentuk sebuah kepercayaan dan pola pikir suatu jemaat.

Alkitab juga menceritakan tentang kemajemukan setiap konteks yang menjadi suatu rangkaian cerita dalam Alkitab, dengan demikian Alkitab dan konteks memiliki kolerasi yang saling berdampingan dalam setiap aplikasinya. Dalam kolerasi (hubungan timbal balik) terdapat dua aspek: pertama, menentukan sikap kita dalam konteks dan pandangan kita terhadap konteks, kedua; konteks turut menentukan pemahaman kita tentang Alkitab, sehingga kontekstualisasi tidak cukup dibutuhkan suatu ajaran yang benar, tetapi lebih kepada tindakan yang benar. Dengan demikian Injil bisa direalisasikan dalam cerita yang aktual dalam kerangka karya penyelamatan Allah yang sudah, sedang dan akan dilakukan oleh Allah. ${ }^{9}$

Dapat dikatakan bahwa dalam berkontekstualisasi, sentralitasnya terletak pada budaya yang dipakai sebagai ruang pertemuan antara Allah dan manusia. Pertemuan tersebut digunakan untuk menarik relevansi Injil ke dalam situasi dan kondisi masyarakat setempat. Seperti halnya yang dilakukan oleh Gereja Masehi Injil Di Timor (GMIT) Imanuel Matepu untuk menyampaikan kebenaran kepada jemaat yang berlatar belakang agama suku (jingitiu). Dimana mereka tidak menolak budaya tersebut melainkan memakai budaya sebagi tempat untuk pemberitaan injil.

Gereja Imanuel melihat bahwa masih banyak jemaat berlatar belakang agama suku, yang masih belum mengerti tentang kebenaran sehingga gereja membuat sebuah ibadah khusus untuk mereka yaitu ibadah profesi. Ibadah ini digunakan pada salah satu tradisi yang sering dilakukan oleh masyarakat setempat yaitu tradisi Puru Hogo. Tradisi Puru Hogo merupakan tradisi doa bersama sebelum pengambilan atau menyadap nira. Ibadah profesi ini berfungsi sebagai penghantar dan doa bersama sebelum menyadap nira. Dan orang Sabu percaya bahwa dengan melakukan tradisi ini maka akan mendapatkan hasil yang terbaik, tidak terjadi kecelakaan saat pengambilan air nira maupun saat memasak air nira untuk diolah menjadi gula atau gula Sabu. ${ }^{10}$

8 Retnowinarti, Agama-Agama Dan Tantangan Kebudayaan (Jakarta: Badan Litbang PGI, 1994), 71.

9 Yanice Janis and Meily M Wagiu, "Pertemuan Injil Dan Kebudayaan: Kajian Kontekstualisasi Kebudayaan Mamidate Kubur'ra Di Jemaat El-Betel Rusoh," Tumou Tou 5, no. 1 (2018): 51.

10 Femi S Nassa Neno, Wawancara Oleh Penulis (GMIT Immanuel Matepu, 2019). 
Ibadah ini berbeda dengan doa yang dilakukan oleh agama suku. Agama suku untuk doa bersama mereka harus mempersiapkan kurban persembahan kepada Tuhan (mone ama), berupa seekor domba yang tidak kedapatan bercacat. Dari kegiatan doa yang dilakukan oleh agama suku, maka gereja membuat ibadah profesi dan memberikan makna baru atau nilai-nilai Kristiani. Nilai-nilai Kristiani yang diberikan gereja yaitu berupa pehaman bahwa dalam kekristenan untuk mendapatkan kesuburan, kekuatan, keselamatan, keuntungan, dan berkat, tidak dengan cara memberikan sesajen atau membunuh kurban, melainkan berdoa dan percaya dengan sungguh-sungguh kepada Tuhan.

GMIT Imanuel Matepu merupakan sebuah gereja yang terletak di Matepu jalan Trans Seba-Mesara. Yang saat ini digembalai oleh Pdt. Femi Susanti Nassa-Neno, S.Th. Di gereja GMIT Imanuel Matepu juga mempunyai visi dan misi yaitu menjadi gereja yang missioner dalam memperluas kerajaan Allah. Berdasarkan Statistik, anggota jemaat berjumlah 926 orang dengan rincian calon Sidi 128 anggota, calon baptis 903 anggota, anggota sidi 512, nikah masehi 216 pasangan dan nikah adat 21 pasangan. Dari jumlah total jemaat, terdapat 99\% jemaat bersuku Sabu dan 10\% nya adalah suku Timor, Rote, dan Alor.

Gereja Imanuel juga mempunyai program pelayanan yang dilakukan dalam membantu jemaat untuk semakin bertumbuh. Program yang dilakukan dalam pelayanan yakni: kebaktian minggu, kebaktian hari raya Gerejawi, pelayanan sakramen perjamuan kudus, pelayanan peneguhan sidi, peleyanan penguburan orang mati, ibadah profesi, ibadah rumah tangga, ibadah kaum bapak, ibadah kaum perempuan, ibadah pemuda, ibadah PAR, ibadah lansia, pelayanan perkunjungan, pelayanan pengucapan syukur, pelayanan perberkatan nikah dan pelayanan diakonia (pelayanan diakonia sakit, duka dan pelayanan akhir tahun untuk lansia).

Ketika program tersebut dijalankan, termaksud didalamnya ibadah profesi maka gereja melihat adanya perubahan yang terjadi dalam jemaat tersebut terkhususnya jemaat yang berlatar belakang agama suku (Jingitiu). Walaupun itu belum seutuhnya mereka tinggalkan setidaknya mereka sudah mau terbuka dengan gereja. Karena tidak mudah bagi gereja untuk mengukur hasilnya, apalagi yang menjadi tolak ukurnya ialah ada yang bertobat atau tidak. Karena proses seseorang bertobat itu, tidak disebabkan oleh satu hal saja melainkan melalui kuasa roh yang menggerakan hati orang itu dan melalui kesempatan-kesempatan baik seperti ibadah, pengalaman hidup dan masih banyak hal lain yang Tuhan ijinkan dalam kehidupan seseorang. Jadi kalau kita bertanya apakah ada orang yang bertobat dan mau mengenal Tuhan serta memberi diri mereka di Baptis, setiap tahunnya ada dan bahkan dalam setahun dibuatkan secara khusus program pelayanan untuk sakramen baptisan kudus. 
Pelayanan Sakramen Kudus tersebut, setiap tahunnya di adakan tiga kali dalam setahun, adapun orang-orang yang mau memberi diri mereka dibaptis dan mau mengenal Tuhan ialah mereka berasal dari agama suku (Jingitiu) dan juga anak-anak dari keluarga yang beragama Kristen. Adapun data yang diperoleh saat gereja melakukan pelayanan Sakramen Baptisan Kudus yakni, pada tahun 2016 anggota baptis berjumlah 850, tahun 2017 anggota Baptis dan calon Baptis berjumlah 931 orang, tahun 2018 anggota Baptis berjumlah 886, dan pada tahun 2019 calon Baptis dan anggota Baptis berjumlah 926. ${ }^{11}$ Dari hasil yang telah dilihat, ini yang menjadi salah satu hal mendorong gereja untuk tetap memberitakan Injil.

Secara umum kontekstualisasi merupakan suatu upaya yang dilakukan oleh sekelompok orang, dalam menyatakan injil melalui budaya yang ada di masyarakat setempat. Kontekstualisasi dalam konteks Kristen merupakan sebuah upaya mengejawantahkan sifat dan karya Allah yang tertulis dalam Alkitab, dan mengimplementasikannya dalam budaya masyarakat setempat. ${ }^{12}$ Yakob Tomatala menegaskan bahwa "Kontekstualisasi" (Contextualisation) berasal dari kata 'konteks' (Context) yang diangkat dari kata Latin "Contextere" yang berarti menenun atau menghubungkan bersama (menjadikan satu). "Contextus" menunjuk kepada apa yang telah ditenun (tertenun), di mana semuanya telah dihubung-hubungkan secara keseluruhan menjadi satu. ${ }^{13}$ Sedangkan Th. Kobong mengemukakan pemahaman yang sederhana mengenai kontekstualisasi yaitu: "apa yang kita tangkap dari Injil Yesus Kristus dengan pengalaman budaya dan adat istiadat kita, dan kita lakukan dalam wujud yang kita pahami sehari-hari, maka hal tersebut merupakan bentuk keterlibatkan kita dalam kontekstualisasi."14 Jadi pengertian dari kedua tokoh diatas dapat disimpulkan bahwa kontekstualisasi merupakan konsep usaha memahami konteks kehidupan suatu masyarakat secara luas dalam dimensi budaya, agama, sosial, ekonomi, dan politik, secara menyeluruh dengan tujuan agar pemberitaan Injil dapat dilakukan dengan baik dan dipahami secara tepat oleh setiap orang yang hidup dalam konteks tersebut.

Jan S. Aritonang menjelaskan bahwa untuk mengembangkan teologi yang kontekstual, perlu adanya keseimbangan antara teks (dalam hal ini isi dan berita) dan konteks. Disatu sisi teologi juga harus tetap setia pada teks dan harus tetap relevan bahkan memberi penghargaan kepada-konteks. Agar apa yang disampaikn tidak membelah salah satunya. ${ }^{15}$

Dalam berkontekstualisasi terdapat beberapa model yang akan dipakai untuk menyatakan injil yang menurut B. Bevans sangat membantu menyatakan injil dalam suatu

11 Erni, Wawancara Oleh Penulis (GMIT Immanuel Matepu, 2019).

12 David J Hasselgrave, Kontekstualisasi (Makna, Metode Dan Model) (Jakarta: BPK Gunung Mulia, 2004), 238.

13 Yakob Tomatala, Penginjilan Masa Kini Jilid 1 (Malang: gandum mas, 1998), 63.

14 Th Kobong, Iman Dan Kebudayaan (Jakarta: BPK Gunung Mulia, 2004), 24.

15 Yunus D A Laukapitang, "Teologi Pembangunan Berbasis Pengembangan Masyarakat Shalom Pada Gereja Kemah Injil Indonesia Daerah Kupang Nusa Tenggara Timur,” Jaffray 14, no. 2 (2016): 243. 
budaya $^{16}$ : pertama. model terjemahan, merupakan model yang menegaskan pada pemberitaan Injil sebagai bentuk yang tidak berubah. Intinya ialah, bahwa pewartaan yang sesungguhnya bagi agama Kristen, bersifat adi-budaya atau adi-kontekstual. Maksudnya, model ini menerjemahkan Injil ke dalam bahasa budaya setempat agar lebih terarah pada tujuan yang diinginkan. Kedua, model antropologi. Di dalamnya terdapat dua model, yaitu: Model yang berpusat pada nilai, kebaikan manusia dan pribadi manusia. Artinya model ini hanya melihat manusia dari karakter, watak, tingkah laku dan perbuatan seseorang. Berikutnya ialah model yang bersifat antropologis, yang memakai kajian ilmu sosial, utamanya ilmu antropologi.

Ketiga, model praktis merupakan cara berteologi yang dibentuk oleh pengetahuan pada tingkat yang sunguh-sungguh serta tingkat aksi berdasarkan yang arahan. Model ini juga berkaitan dengan pemindaian makna yang memberi sumbangsi kepada rangkaian perubahan sosial. Dengan demikian ilham yang diperoleh bukan dari teks-teks klasik atau tingkah laku klasik, namun dari kenyataan masa kini dan peluang-peluang masa depan. Keempat, model sintesis. Model ini berusaha melihat bahwa Injil dan tradisi, sama pentingnya dengan pengalaman manusia, termasuk kebudayaan. Kelima, model transcendental lebih mementingkan pengalaman manusia, tanpa melihat dari segi pengetahuan, sikap, watak dan nilai kebaikan seseorang. Makanya model ini terkesan mengambang dan sulit untuk dilakukan. Dan yang terakhir yaitu budaya tanding, merupakan budaya yang mengoreksi budaya lain dengan tujuan agar tidak sama dengan budaya yang lainnya, dan mambuat perubahan.

Dalam masalah hubungan Injil dan kebudayaan Niebuhr juga menguraikan lima sikap yang diperlihatkan oleh orang Kristen di sepanjang sejarah gereja terhadap kebudayaan ${ }^{17}$ : Sikap radikal, sikap akomodatif, sikap sintetik, sikap dualistik dan sikap transformatif. Pertama, sikap radikal merupakan Sikap yang tidak mengakui hubungan antar iman dan budaya. Iman datang dari Tuhan, sedangkan budaya datang dari bawah, bawah itu cemar karena dosa sehingga Iman selalu menghakimi kebudayaan karena kebudayaan selalu jahat.

Kedua, akomodatif. Dalam hal ini, tidak mempertentangkan iman dan kebudayaan. Nilai-nilai yang ada di dalam masyarakat dipandang selaras dengan nilai Imani. Ketiga, sikap sintetik merupakan sikap ini sebenarnya merupakan bagian dari sikap radikal dan akomodatif, dimana baik Injil maupun kebudayaan diterima dalam kesatuan yang saling mengisi. Keempat, sikap dualistik memandang bahwa manusia hidup dalam dua kewarganegaraan, yang memandang bahwa menjadi warga negara Surga dan warga negara dimana ia tinggal.

Kelima, sikap tranformatif yaitu dimana dalam sikap ini, Iman harus menjadi warna atau napas kebudayaan. tidak ada budaya Kristen, yang ada ialah budaya setempat yang

16 Titus Tara, "Memahami Model-Model Teologi Kontekstual Stephhen B Bevans Dalam Konteks Budaya Ende Lio Sebagai Bagian Dari Kejujuran Berteologi,” Atma Reksa 21, no. 1 (2017): 3.

17 Emmanuel Gerrit Singgih, Berteologi Dalam Konteks (Jakarta: BPK Gunung Mulia, 2000), 36. 110 | Copyright $@$ 2020, CARAKA, ISSN 2722-1407 (Cetak), 2722-1393 (Online) 
bernapas atau diwarnai iman Kristen. Jadi, ada sikap kritis dan selektif sehingga yang terjadi ialah bukan soal menerima atau menolak kebudayaan tetapi menerima bagian yang mana dari budaya dan menolak bagian yang mana dari budaya.

Dari kelima sikap yang dipaparkan oleh Emanuel G. Singgit, yang menjelaskan tentang bagaimana sikap gereja terhadap kebudayaan maka peneliti melihat ada kesamaan dengan yang dipaparkan oleh B. Bevans. Di mana yang pertama sikap radikal lebih kearah model terjemahan, karena sama-sama mempertahankan Iman dan ketika Injil itu disampaikan tidak mengalami perubahan atau tidak berubah, sehingga ketika seseorang bertobat dia harus meninggalkan apa yang pernah dipercayai atau yang pernah dianut sebelumnya. Kedua, sikap akomodatif lebih kearah model antropologi dan model transendental, karena lebih mementingkan pengalaman manusia dalam budaya baik dalam perubahan sosial serta lingkungan sosial dan sejarah yang dianggap sebagai nilai-nilai yang juga dikejar dalam penghayatan iman.

Ketiga, sikap sintetik, sikap tranfomatif lebih ke model sintesis. Karena ketiga tindakan ini berusaha mengambil jalan tengah, dimana Injil maupun budaya sama pentingnya dalam satu kesatuan yang saling mengisi dengan pengalaman manusia, termaksud di dalamnya kebudayaan. Sehingga terlihat bahwa budaya setempat diwarnai oleh iman Kristen. Dan terakhir sikap dualistik lebih ke arah budaya tanding, sama-sama mengakui Injil dan mengakui budaya. Sehingga mereka bisa melakukan kedua-duanya dengan bersamaan.

Proses berteologi ini perpangkal pada pengalaman dan melalui komunikasi dengan tradisi-tradisi kristiani kembali ke pengalaman. Proses berteologi ini ditempuh melalui empat momen yakni ${ }^{18}$ : pertama, momen pengalaman. Teologi berfungsi untuk mendukung pengalaman iman Gereja yang konteks, yang berusaha hidup Kristus dan terlibat dalam pelayanan. Teologi yang fungsional berpatokan pada pengalaman kontekstual dalam menghayati kehidupan imannya. Kedua, momen keprihatinan Iman. Yang menjadi titik-tolak seluruh kegiatan berteolgi ialah pengalaman iman. Keprihatinan iman merupakana tanggapan orang yang beriman dalam menanggapi kehidupan yang nyata. Pengalaman iman bisa juga terjadi dalam bentuk tindakan religius dan juga dalam bentuk tindakan moral. Dua hal ini tidak dapat dipisahkan, namun perlu dibedakan untuk merumuskan keprihatinan iman secara tajam.

Ketiga, momen sintesis teologi. Suatu tindakan teologis yang tidak dapat ditinggalkan ialah mendengarkan tradisi-tradisi Kristiani. Tradisi-tradisi Kristiani dimengerti secara luas, yaitu apa saja yang menampilkan iman akan Yesus Kristus "Iman timbul dari pendengaran" (Roma 10:17). Dalam mendengarkan tradisi-tradisi yang ada, harus mempunyai komunikasi 
yang baik agar tidak terjadi kesalahapaham. Usaha kontekstualisasi teologi tidak hanya berkaitan dengan pandangan konteks lokal-aktual sekarang ini, melainkan terpretasi konteks alkitabiah, konteks sistematis, maupun konteks pernyataan-pernyataan doktrin lainnya. Dan Keempat, momen rencana pastoral. Berteologi dengan titik tolak pengalaman aktual dan melalui komunikasi dengan tradisi-tradisi kristiani kembali ke pengalaman lagi, mengandung ciri dialektik antara aksi dan reflesi, antara praktek dan teori. Refleksi teologis berkaitan erat dengan praktis dalam hubungan dialektis. Teologi bermaksud untuk mendukung penghayatan iman dan iman itu merupakan penyerahan diri kepada Allah.

Dari keempat proses tersebut dapat dilihat bahwa dalam melakukan penjangkauan jiwa, sebuah organisasi atau gereja harus memulai dari pengalaman iman seseorang kepada yang dipercayainya, yaitu pengalaman hidup, dengan cara mendengarkan pengalaman apa yang dialami dalam penyerahan iman mereka kepada yang dipercayai. Karena dari pengalam hidup seseorang, gereja bisa memilih pendekatan yang tepat agar Injil tersebut bisa disampaikan dengan baik dan yang paling penting yaitu evaluasi, karena dari evaluasi gereja bisa mengetahui sejauh mana proses itu berlangsung.

\section{Tradisi Puru Hogo}

Puru Hogo adalah tradisi berdoa bersama kepada Allah yang mereka percayai sebelum menyadap nira dan memasak gula. Tradisi ini dilakukan setahun sekali pada tanggal dua belas bulan Juni. Tradisi Puru Hogo menjadi salah satu tradisi yang penting bagi masyarakat Sabu, karena mereka percaya bahwa dengan melakukan acara ini maka akan mendapatkan hasil hasil yang terbaik, dan tidak ada yang mendapat kecelakaan saat pengambilan air nira maupun saat memasak air nira untuk diolah menjadi gula Sabu.

Prosesi Tradisi ini dilakukan di tempat dimana akan dilakukan proses memasak air nira menjadi gula. Sebelum tradisi ini dilakukan oleh masyarakat maka pertama kalinya yang akan melakukan tradisi ini yaitu tua adat, sebagai pembuka sebelum orang Sabu memulai pekerjaannya. Setelah tua adat melakukan tradisi Puru Hogo barulah disusul oleh masyarakat yang akan menyadap nira dan memasak gula. Setiap keluarga yang akan melaksanakan tradisi ini maka ada beberapa hal yang harus dipersiapkan yaitu domba yang baik dan tidak sakit, sebuah tempat yang berbentuk bulat seperti mangkuk yang terbuat dari anyaman daun lontar, orang Sabu menyebutnya dengan nama kerigi, dan sajian makanan untuk dipersembahkan seperti hati, usus besar dan kecil, lambung, dada, dan kaki bagian belakang.

Saat prosesi ini dilaksanakan maka seluruh keluarga akan berkumpul bersama untuk mengikuti acara ritual adat dan tetangga yang diundang saja. Biasanya untuk baju tidak ditentukan, para anggota keluarga yang melakukan acara ritual ini bebasa memakai baju apa 
saja, tetapi tidak boleh memakai celana hanya diperbolehkan memakai sarung adat Sabu. Karena dengan memakai sarung adat Sabu, itu melambangkan kesetiaan pada adat dan budaya sendiri.

Menurut kepercayaan orang Sabu dalam tradisi ini, ada tiga orang sebagai perantara mereka kepada Deo Ama atau tuhan, yaitu appu moto, tobo djawa dan rede djawa. Deo Ama merupakan sebutan nama Tuhan atau menurut orang Sabu Allah Bapak pencipta alam semesta. Sedangkan Appu Moto, Tobo Djawa dan Rede Djawa merupakan manusia yang pertama kalinya yang tinggal di pulau Sabu dan memulai memasak gula dan menyadap nira. Menurut mereka Tobo Djawa adalah seorang yang berasal dari Pulau Jawa yang pandai dalam menyadap nira, sedangkan Rede Djawa dan Appu Moto adalah orang yang pintar dalam memasak gula.

Sampai sekarang mereka percaya bahwa ketiga orang inilah yang bisa menyampaikan segala doa mereka kepada Allah Bapak, sebelum memulai pekerjaan mereka. Pada saat mempersembahkan makanan yang sudah disiapkanpun, harus memilih salah satu anggota keluarga karena ada pantangan yang tidak boleh dilanggar oleh orang tersebut. Setelah mereka mempersembahkan makanan kepada ketiga orang tersebut maka selanjutnya ketua adat akan menaikan doa, tetapi orang-orang yang mengikuti acara tersebut hanya boleh mengucapkan doa secara pribadi tanpa mengeluarkan suara. ${ }^{19}$

Menurut masyarakat Sabu ketika mereka melakukan tradisi ini, maka tidak akan terjadi hal-hal yang merugikan mereka. Hal-hal yang merugikan mereka seperti, kecelakaan yang terjadi saat menyadap nira atau pengambilan air nira dan saat proses memasak gula. Bahkan mereka juga percaya bahwa setiap pohon yang akan mereka menyadap nira, pohonnya akan subur, banyak air nira yang mereka hasilkan, gula yang mereka masakpun bagus, dan penghasilan yang mereka dapat bisa memenuhi kebutuhan sehari-hari.

Berbicara mengenai tradisi Puru Hogo, Pdt. Femi Susanti mengemukakan bahwa dalam memahami tradisi sangatlah penting, karena lewat tradisi gereja bisa masuk memberitakan firman Tuhan. Khusunya dalam tradisi Puru Hogo gereja melihat ada nilai baik dalam tradisi tersebut, yang gereja katakan sebagai kebergantungan manusia kepada kuasa yang melebihi kuasa manusia yaitu Allah atau orang Sabu menyebutnya sebagai Deo. Dalam tradisi Puru Hogo orang Sabu menunjukkan bahwa mereka bergantung kepada kuasa tuhan melalui ritus tersebut. Hal itu yang ditarik gereja untuk memahami bahwa setiap manusia harus bergantung kepada Allah yang memberi hidup, sehingga mereka harus memberikan waktu untuk berdoa kepada Allah, agar apapun yang mereka kerjakan dalam sehari, seminggu, sebulan bahkan setahun, akan diberkati Tuhan. 
Dengan ini, sikap yang dilakukan gereja terhadap tradisi Puru Hogo yaitu dimana gereja menerima tradisi ini tetapi gereja sendiri tidak seutuhnya menerima tradisi tersebut, melainkan gereja berusaha memberikan makna atau nilai baru secara kekristenan. Karena gereja melihat bahwa sebelum orang Sabu bekerja, mereka berdoa kepada allah yang mereka sebut sendiri sebagai Deo, agar keselamatan, kekuatan bisa mereka trima. sehingga itu juga yang diambil oleh gereja tetapi melalui ibdah profesi atau tata cara dengan memakai liturgi yang dibuat oleh gereja sendiri. Ibadah profesi yang dibuat oleh gereja agar jemaat bisa mengerti bahwa sumber kekuatan, sumber penghasilan, sumber pertolongan, hanya ada dalam tangan Tuhan dan tidak ada dalam tangan yang lain selain Tuhan, bahkan hidup pekerjaan mereka itu semua tergantung pada tuntunan Tuhan. ${ }^{20}$

Sikap penerimaan dan tindakan yang dilakukan, gereja tahu bahwa hal itu baik dilakukan agar jemaat tidak seutuhnya bergantung pada tradisi itu. Hal ini dikarenakan gereja tidak ingin jemaat ikut-ikutan dalam kehidupan gaya lama yang beranggapan bahwa, ketika mereka tidak melakukan ritual tersebut mereka tidak mendapat hasil yang baik. Sehingga mereka lupa akan kuasa Tuhan yang melampui apapun juga. Padahal lebih dari yang mereka ketahui bahwa kehidupan manusia, baik usaha, kekuatan, pertolongan, berkat, keberhasilan, itu semua ada dalam tangan Tuhan. Sehingga gereja berusaha membuat program ibadah profesi bagi kaum petani agar bisa membuka atau merubah cara berpikir mereka dan bisa mengerti bahwa sebelum bekerja mereka harus melibatkan Tuhan.

Dari apa yang telah dilakukan oleh gereja Imanuel Matepu, peneliti melihat bahwa gereja tersebut telah melakukan proses kontekstualisasi. Gereja sendiri tidak menolak tradisi tersebut tetapi gereja berusaha untuk memberikan makna baru atau nilai-nilai kristiani kepada mereka melalui ibadah profesi. Proses kontekstualisasi yang di lakukan atau yang diterapkan oleh gereja lebih ke model sintesis atau transformatif. Karena model ini, iman harus menjadi warna dalam kebudayaan sehingga keduanya saling mengisi. Model ini juga tidak mempersoalkan tentang menerima atau menolak kebudayaan, tetapi menerima bagian mana dari budaya dan menolak bagian dari budaya.

Injil yang disampaikan akan memberikan dampak tranformatif yang luar biasa, jika diterima dengan tulus dan terbuka. Dengan Injil, manusia yang percaya dapat dibebaskan dari penghukuman dosa bahkan dapat memulihkan setiap harapan untuk diselamatkan. Seperti yang dikatakan oleh Rasul Paulus bahwa "sebab aku mempunyai keyakinan yang kokoh dalam Injil, karena Injil adalah kekuatan Allah yang menyelamatkan setiap orang percaya, pertamatama orang Yahudi, tetapi juga orang Yunani" (Rom. 1:16) dan "setiap orang yang percaya kepada-Nya tidak akan binasa melainkan akan beroleh hidup yang kekal” (Yoh. 3:16). Hanya 
Injil yang dapat mentransformasikan keadaan rohani manusia yang sudah berdosa dan layak dihukum, menjadi anak pilihan-Nya dan diselamatkan melalui karya Yesus Kristus. Bukan hanya itu saja, dengan hadirnya Injil dalam kehidupan manusia dapat mengubah cara pandang seseorang tentang sesuatu, baik dalam menghargai waktu, menghargai nilai hidup manusia, pendidikan maupun dalam kehidupan sosial. ${ }^{21}$

Sehingga model ini juga memperlihatkan agar kita sebagai orang percaya tidak anti terhadap budaya, tetapi dengan kehadiran kita dalam budaya dapat memberikan sesuatu yang berbeda atau suasana baru. Baik dapat membentuk pola pikir yang benar serta membantu dalam pertumbuhan iman percaya mereka kepada Tuhan tanpa menolak budaya tersebut. Sebenarnya gereja dan orang percaya hadir kedalam budaya yaitu untuk memperbaiki dan memperharui cara pandang mereka tentang sesutu agar tetap pada dasar kekristenan.

Hasil yang didapatkan oleh gereja ketika menerapkan ibadah profesi ini, adanya perubahan-perubahan yang gereja dapatkan yakni gereja mengalami pertambahan jemaat, pertambahan anggota sidi dan pertambahan anggota baptis. Gereja Imanuel Matepu mulai menjalankan ibadah profesi, dari tahun 2014 sampai 2020. Namun pada tahun 2014 dan 2015 dari pihak Gereja belum menata data statistik dengan baik, sehingga gereja sendiri belum bisa memastikan berapa jumlah pertambahan jemaat pada tahun tersebut. Tetapi pada tahun 2016 sampai 2019 barulah di tata ulang oleh para majelis untuk mengetahui berapa jumlah pertambahan jemaat yang terjadi.

Pada tahun 2016 jemaat berjumlah 878 jiwa, tahun 2017 berjumlah 928, tahun 2018 berjumlah 940 jiwa dan pada tahun 2019 berjumlah 956. Tetapi untuk data statistik tahun 2020 belum dicantumkan dikarenakan gereja melakukan pendataan pada akhir tahun. ${ }^{22}$ Dari hasil tersebut peneliti melihat bahwa ada hasil yang gereja capai walaupun itu tidaklah mudah, apalagi memberitakan injil ditengah masyarakat yang masih sangat kental dan masih memegang kuat dengan budaya setempat. Tetapi dari hasil tersebut membuat gereja lebih paham bahwa membawa mereka mengenal Tuhan tanpa menolak budaya mereka, itu lebih baik daripada membenci terhadap budaya.

Dalam hal ini peneliti melihat ada upaya yang dilakukan oleh gereja dalam memperkenalkan injil kepada masyarakat melalui budaya yang ada. Seharusnya itu juga yang dilakukan gereja-gereja saat ini agar tidak ada lagi penolakan terhadap budaya, melainkan memakai budaya sebagai jembatan untuk jalannya pemberitaan Injil kepada masayarakat, seperti yang dilakukan gereja GMIT Matepu dalam tradisi Puru Hogo. Gereja GMIT melakukan proses pemberian makna baru dengan cara melihat kondisi, keadaan dalam 
masyarakat dan jemaatnya, setelah itu Pendeta mengkomunikasikan dengan mejelis gereja. Dimana gereja memberikan pemahaman yang benar tentang Allah karena saat orang Sabu melakukan ritus tersebut, mereka tidak berfokus kepada Allah sebagai Tuhan Yesus Kristus tetapi pada allah (Deo Ama) dengan pembagian perannya masing-masing.

Ketika orang Sabu melakukan ritus Puru Hogo berarti mereka berdoa kepada talo nawa (pembawa air gula) dan Deo Haba Wadu (yang mengendalikan musim kemarau). Dari pemahaman yang dimililiki orang Sabu, gereja juga berusaha memberikan pemahaman tentang Allah secara kekristenan sehingga mereka bisa mengerti dan memahami kepada siapa mereka harus menyembah. Selain itu gereja juga memberikan pemahaman bahwa untuk mendapatkan kekuatan, keberhasilan, kesehatan, keseburan, hanya melalui doa kepada Yesus Kristus tanpa adanya persembahan dan pantangan. Kerena bagi orang Sabu ketika mereka tidak melakukan ritus ini serta melanggar aturan yang telah dibuat maka akan terjadi kerugian dalam diri mereka. sehingga gereja berusaha untuk merubah cara berpikir mereka, lewat ibadah profesi ini. Karena didalam Kristus tidak ada pantangan dan persembahan karena semuanya sudah digenapi diatas kayu salib.

Peneliti setuju dengan pemahaman serta tindakan yang dilakukan oleh Gereja Maeshi Injili Di Timor (GMIT) Matepu. Sebagai orang percaya dengan hadirnya gereja seharusnya memberikan makna baru serta pehaman yang baru tentang tradisi guna jemaat mengalami perubahan dalam memahami sebuah tradisi. Karena semua pekerjaan, keberhasilan, kesehatan, berkat, keselamatan, bahkan kesehatan semuanya itu berada dalam tangan Tuhan. Dan Tuhan yang kita sembah adalah Tuhan tanpa syarat.

Siapapun bisa mendapatkan dan menerima semua itu secara cuma-cuma, hanya yang di minta serakan dan percaya kepada Dia dengan seutuhnya maka apapun yang dikerjakan berhasil, bahkan akan ditambahkan kepada kita. Jadi disini gereja mempunyai peluang agar Injil bisa disampaikan melalui kegiatan dalam kehidupan sehari-hari, bahkan bisa menolong masyarakat dan jemaat dalam meningkatkan Iman kepercayaan mereka kepada Tuhan.

\section{KESIMPULAN}

Kontekstualisasi merupakan suatu upaya yang dilakukan oleh sekelompok orang, dalam menyatakan Injil melalui budaya yang ada di masyarakat. Kontekstualisasi juga di artikan sebagai upaya untuk memberitakan berita tentang pribadi, karya, Firman dan kehendak Allah dalam cara yang setia pada penyataan ilahi yang khususnya diungkapkan dalam Alkitab, dan bermakna bagi khalayak dalam budaya mereka masing-masing.

Gereja Masehi Injili Di Timor (GMIT) Matepu tidak menolak tradisi Puru Hogo, melainkan memberi makna baru terhadap tradisi tersebut. Menyadari bahwa sebagai gereja 
yang menaungi jemaat dengan mayoritas yang berlatar belakang agama suku (Jingitiu), harus bijaksana dalam memaparkan pemahamn terhadap tradisi. Sehingga penggembalaan terus menerus dilakukan agar jemaat memahami bagaimana hidup sesuai dengan kebenaran firman Tuhan. Gereja harus berani menerima tradisi jika tradisi yang ada sesuai dengan kebenaran firman Tuhan. Dari itulah gereja dapat mentransformasi tradisi dengan memberi makna baru agar tradisi tidak melenceng dari kebenaran firman Tuhan. Selain memberikan pemahaman baru, gereja juga menjalankan program ibadah profesi agar mereka tidak lagi melenceng dari kebenaran secara kekristenan.

\section{DAFTAR PUSTAKA}

Darmaputera, Eka. Konteks Berteologi Di Indonesia. Jakarta: BPK Gunung Mulia, 2004.

Erni. Wawancara Oleh Penulis. GMIT Immanuel Matepu, 2019.

Hariprabowo, Y. "Misi Gereja Di Tengah Pluralitas Agama Dan Budaya." Orientasi Baru 18, no. 1 (2009): 13-14.

Hasselgrave, David J. Kontekstualisasi (Makna, Metode Dan Model). Jakarta: BPK Gunung Mulia, 2004.

Janis, Yanice, and Meily M Wagiu. "Pertemuan Injil Dan Kebudayaan: Kajian Kontekstualisasi Kebudayaan Mamidate Kubur'ra Di Jemaat El-Betel Rusoh.” Tumou Tou 5, no. 1 (2018): 51.

Kobong, Th. Iman Dan Kebudayaan. Jakarta: BPK Gunung Mulia, 2004.

Laukapitang, Yunus D A. "Teologi Pembangunan Berbasis Pengembangan Masyarakat Shalom Pada Gereja Kemah Injil Indonesia Daerah Kupang Nusa Tenggara Timur." Jaffray 14, no. 2 (2016): 241-261.

Lola, James A. "Iman Kristen Dan Budaya Popular.” Visio Dei: Jurnal Teologi Kristen 1, no. 1 (2019): 13-14.

Neno, Femi S Nassa. Wawancara Oleh Penulis. GMIT Immanuel Matepu, 2019.

Prayogi, Winfrid. "Mencari Esensi Dan Misi Gereja Dalam Konteks Indonesia Awal Abad 21." Veritas : Jurnal Teologi dan Pelayanan 1, no. 1 (2000): 10.

Retnowinarti. Agama-Agama Dan Tantangan Kebudayaan. Jakarta: Badan Litbang PGI, 1994. Rihi, Huki. Wawancara Oleh Penulis. Ledeana, 2019.

Samarenna, Desty. "Berteologi Dalam Konteks Indonesia Modern." Evangelikal: Jurnal Teologi Injili dan Pembinaan Warga Gereja 1, no. 1 (2017): 25.

Setiawan, David Eko. "Dampak Injil Bagi Transformasi Spiritual Dan Sosial." BIA': Jurnal Teologi dan Pendidikan Kristen Kontekstual 2, no. 1 (2019): 83-93.

Singgih, Emmanuel Gerrit. Berteologi Dalam Konteks. Jakarta: BPK Gunung Mulia, 2000.

Sukmadimata, Nana Syaodih. Metode Penelitian Pendidikan. Bandung: Remaja Rosdakarya, 2011.

Tara, Titus. "Memahami Model-Model Teologi Kontekstual Stephhen B Bevans Dalam Konteks Budaya Ende Lio Sebagai Bagian Dari Kejujuran Berteologi.” Atma Reksa 21, no. 1 (2017): 3-6.

Tari, Ezra. "Teologi Tongkonan: Berteologi Dalam Konteks Budaya Toraja." EPIGRAPHE: Jurnal Teologi dan Pelayanan Kristiani 2, no. 2 (2018): 5.

Tomatala, Yakob. Penginjilan Masa Kini Jilid 1. Malang: gandum mas, 1998.

Warjianto, Ayub, and Fibry Jati Nugroho. "Teologi Penghormatan.” Visio Dei: Jurnal Teologi Kristen 2, no. 1 (2020): 147-167. 